Original article

\title{
MOLECULAR CHARACTERISATION OF NEWCASTLE DISEASE VIRUS EXOTIC ISOLATE IN EAST JAVA, INDONESIA
}

\author{
N. P. KUSUMARAHAYU ${ }^{1}$, N. PUTRI ${ }^{1}$, R. ERNAWATI ${ }^{1}$, J. RAHMAHANI $^{1}$, \\ S. SUWARNO ${ }^{1,2} \&$ F. A. RANTAM ${ }^{1,2}$ \\ ${ }^{1}$ Laboratory of Virology and Immunology, Department of Microbiology, Faculty of Veteri- \\ nary Medicine, Airlangga University, Surabaya, Indonesia; ${ }^{2}$ Airlangga Disease Research \\ and Prevention Center-One Health Collaborating Center (ADPRC-OHCC), Airlangga Uni- \\ versity, Surabaya, Indonesia
}

\section{Summary}

Kusumarahayu, N. P., N. Putri, R. Ernawati, J. Rahmahani, S. Suwarno \& F. A. Rantam, 2021. Molecular characterisation of Newcastle disease virus exotic isolate in East Java, Indonesia. Bulg. J. Vet. Med., 24, No 2, 191-199.

Newcastle disease virus (NDV) is ssRNA paramyxovirus causing clinical signs, varying from subclinical infections to $100 \%$ mortality in infected chickens. Haemagglutinin-neuraminidase (HN) protein has an important role related to infection and pathogenesis, therefore, the protein was characterised in this study. Samples were collected from 45 cloacal swabs of native chickens. They were isolated by inoculating in specific pathogen-free embryonated eggs. Molecular detection of NDV was done by reverse transcriptase polymerase chain reaction (RT-PCR) encoding HN protein. RT-PCR for $\mathrm{HN}$ gene of NDV generated DNA fragments sized $503 \mathrm{bp}$, which were then sequenced using ABI Prism. The results have shown that virus isolates were mostly lentogenic and might contribute to outbreak in East Java, Indonesia. Based on this fact, NDV infected native chickens can act as reservoir and contribute to outbreak in the poultry. Our study provides baseline information on genetic characteristics of NDV circulating in East Java and serves as a basic work for further research.

Key words: gene coding HN, NDV, native chicken, new variants, RT-PCR

\section{INTRODUCTION}

Indonesia is an endemic area of Newcastle disease virus (NDV), which is spread all over Indonesia. The disease, which is known to have infected over 200 bird species, is spreading rapidly, both morbidity and mortality of NDV infection can reach $100 \%$ (OIE, 2012). NDV outbreaks dur- ing 2009-2010 (Xiao et al., 2012) and during 2011-2012 (Dharmayanti et al., 2014; Miller et al., 2015) with $70-80 \%$ mortality of poultry have caused a total loss of approximately US\$ 10.011 million due to the decrease in production and management cost (Dharmayanti et al., 
2014). Preventions such as routine vaccination and proper management had been done but the implementation of these preventions is still not enough to preclude the outbreak of NDV (Dimitrov et al., 2017).

Prophylactic measures can be done through vaccination. Vaccination against ND is done to control the impact of both low virulent and virulent NDV infections (Su et al., 2018). Vaccines are many types; live attenuated vaccine based on highly immunogenic NDV strains of low or intermediate virulence, and inactivated vaccines (Bello et al., 2018). It is noted that the NDV strain circulating in Indonesia is distinct compared to the commercial vaccine used. NDV strains in Indonesia belong to class II genotypes I, VI, and dominantly VII (Dharmayanti et al., 2014) while the vaccine virus that is conventionally used is LaSota strain from class II genotype II. Based on a study of Xiao et al. (2012), analysis of the serologic response to the vaccination and challenge showed that vaccinated birds produced higher $\mathrm{HI}$ and neutralising antibody titres against genotype-matched viruses than genotype-mismatched virus therefore genotype homology between vaccine virus and the infecting NDV has an important role to reduce virus shedding in the environment (Miller at al., 2013).

The aim of this study was to perform a molecular characterisation of NDV from native chickens based on the HN protein coding gene. This is very important in order to develop new vaccines.

\section{MATERIALS AND METHODS}

\section{Sample collection}

Newcastle disease virus (NDV) isolates were gathered from cloacal swabs of forty-five female native chickens aged
14-15 weeks weighing $1.5-2 \mathrm{~kg}$ from several regions of East Java, Indonesia. The research was approved by IACUC with the ethical clearance No. KE 105.07.2018 under guidance of Ethical Clearance Commission Faculty of Veterinary Medicine, Airlangga University.

\section{Mean death time (MDT)}

To determine the biological characteristics of ND viruses based on pathotype the OIE standard was used, briefly, fresh sterile phosphate buffered saline was used for serial dilution of allantoic fluid by tenfold dilution between $10^{-5}$ and $10^{-9}$ for inoculation of $0.1 \mathrm{~mL}$ into cavity of each of five 10-day-old embryonated SPF chicken eggs and then incubated at $37{ }^{\circ} \mathrm{C}$. Meanwhile each egg was investigated twice daily for seven days, and embryo deaths were recorded. MDT was the mean time in hours for the minimal lethal dose to kill all of the inoculated embryos, and the minimal lethal dose was the highest virus dose causing all of the embryos inoculated with virus with a specific dilution to die (OIE, 2012).

\section{Intracerebral pathogenicity index (ICPI)}

To determine the biological characteristics of ND viruses based on the pathotype, the OIE standard was used. Allantoic fluid of harvested virus was diluted to 1:10 using sterile PBS. Then it was inoculated intracerebrally to day-old chickens at 0.05 $\mathrm{mL}$ diluted virus and then examined every $24 \mathrm{~h}$ for eight days. Birds were scored with 0 if normal, 1: if sick and 2: if dead. ICPI was the mean score per bird per observation over the eight-day period (OIE, 2012; Nakamura et al., 2014).

\section{$R N A$ virus extraction}

RNAs of the viruses were extracted from allantoic fluids using Trizol LS reagen 
(Invitrogen, Carlsbad, CA) following the manufacturer's instructions. Extracted RNA was stored at $-80{ }^{\circ} \mathrm{C}$.

Reverse transcriptase polymerase chain reaction ( $R T-P C R)$

In each reaction $12.5 \mu \mathrm{L}$ of reaction mix solution, $1 \mu \mathrm{L}$ of each reverse and forward primers (forward primer 3- AGTTAGCC AGTTGCGTTAG-5, and reverse primer 5-AACCTGATCCTGTATAGGC-3 with length DNA 503 bp with concentration 20 $\mathrm{pmol} / \mathrm{L}), 2 \mu \mathrm{L}$ of RNA, $1 \mu \mathrm{L}$ of ssIII/ Platinum Taq Polymerase (SuperScript ${ }^{\circledR}$ III One-Step RT-PCR System with Platinum $^{\circledR}$ Taq DNA Polymerase, Invitrogen by Thermo Fisher Scientific) were added. Finally nuclease free water was added until the volume reached $25 \mu \mathrm{L}$. The thermocycle machine was set at $95{ }^{\circ} \mathrm{C} \mathrm{Lid}$ on, $94{ }^{\circ} \mathrm{C}$ for predenaturation stage for 10 mins, $94{ }^{\circ} \mathrm{C}$ for denaturation stage for a minute, $57{ }^{\circ} \mathrm{C}$ for annealing stage for a minute, $72{ }^{\circ} \mathrm{C}$ for extention stage for 2 minutes and $72{ }^{\circ} \mathrm{C}$ for final extension stage for 10 minutes (MJ Mini ${ }^{\mathrm{TM}}$ Personal Thermal Cycler, Bio-Rad). The cycles for the PCR were repeated 40 times in denaturation stage. The amplicons (product of PCR) were stored at $4{ }^{\circ} \mathrm{C}$.

RT-PCR products were visualised by agarose gel electrophoresis at $100 \mathrm{~V}$ for 60 min (Electrophoreses Machine, Power$\mathrm{Pac}^{\mathrm{TM}}$ Basic Power Supply, Bio-Rad). The presence of marker and PCR product bands was observed under UV light.

\section{Sequencing}

The PCR product was purified using QIAquick ${ }^{\circledR} \quad$ PCR Purification Kit (Qiagen) and labelled after the opurificaiton. BigDye ${ }^{\circledR}$ Terminator Sequencing RR-100 $(1.5 \mu \mathrm{L})$ was put into a $100 \mu \mathrm{L}$ tube and $5 \mu \mathrm{L}$ BigDye ${ }^{\circledR}$ Terminator $5 \times$ sequencing buffer, $5 \mu \mathrm{L}$ of purified ampli- con, $1.5 \mu \mathrm{L}$ of forward and reverse primers and $7 \mu \mathrm{L}$ of nuclease free water (Free Water, Promega) were added into the tube, mixed then spinned down carefully.

Tubes were transferred into a thermal cycler (ABI $3130 \quad x L$ GENETIC ANALYZER, Applied Biosystem Inc by Thermo Fisher Scientific). The result of sequencing was shown as symbols that was determined by International Union of Pure and Applied Chemistry (IUPAC).

\section{Molecular analysis}

The sequence of nucleotides was analysed using Biological Sequence Alignment Editor (BioEdit) version 7.0.5.3 (BioEdit software, Ibis Therapeutics) and Molecular Evolutionary Genetics Analysis (MEGA) (Tamura et al., 2013). Both forward and reverse sequences were combined using MEGA version 6.06 then edited by using BioEdit version 7.0.5.3. Reference sequence (GenBank) was used to edit the samples was NDV LaSota. Then the homology analysis was done by comparing the partial haemagglutininneuraminidase protein of the isolated virus strain compared to Indonesian isolates submitted in GenBank. Reference sequence can be accessed in GenBank. The homology was measured using global alignment (Needleman-Wunsch algorithm) of two nucleotides sequences via NCBI. To predict the B cell epitope, methods provided by immune epitope database (http://toolseidb.ofg/bcell/) with default threshold BepiPred value of 0.35 were used (Anayet et al., 2013).

\section{RESULTS}

Biological characterisation of isolated NDV

Five out of forty-five samples showed positive results of HA. Those samples we- 
Molecular characterisation of Newcastle disease virus exotic isolate in East Java, Indonesia

Table 1. Biological characterisation of NDV isolated in Surabaya

\begin{tabular}{lllcc}
\hline NDV Isolate & Location & Pathotype & MDT (hpi) & ICPI \\
\hline Sby-Ck01/13 & Surabaya & Lentogenic & 100 & 0.12 \\
Blt-Ck02/13 & Blitar & Lentogenic & 120 & 0.12 \\
Blt-Ck03/13 & Blitar & Lentogenic & 110 & 0.25 \\
Sby-Ck35/16 & Surabaya & Lentogenic & 120 & 0.12 \\
Pas-Ck36/16 & Pasuruan & Lentogenic & 100 & 0.37 \\
Positive control & Surabaya & Lentogenic & 120 & 0.12 \\
\hline
\end{tabular}

Note: Mean death time in 9-day-old SPF embryonated chicken eggs (hours) (velogenic $<60$, mesogenic 60-90, lentogenic $>90$ ). Intracerebral pathogenicity index in 1-day-old chickens (lentogenic $<0.7$, mesogenic $0.7-1.4$, velogenic $1.4-2.0$ ).

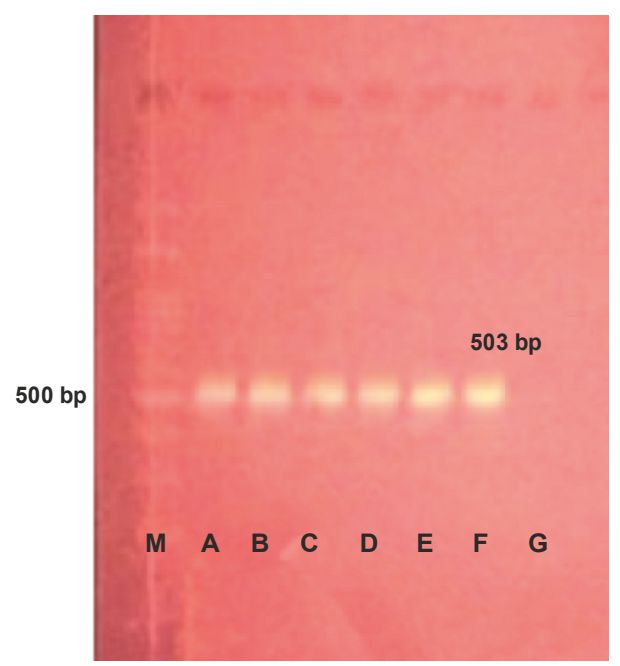

Fig. 1. The RT-PCR amplification results of the HN gene of NDV. Lane M: marker DNA ladder 100 bp. Lanes B: Sby-Ck01 (503 bp); C: Blt-Ck02 (503 bp); D: Blt-Ck03 (503 bp), E: Sby-Ck35 (503 bp), F: Pas-Ck36 (503 bp) are samples. Lane A: positive control (503 bp); Lane G: negative control.

re Sby-Ck01/13, Blt-Ck02/13, BltCk03/13, Sby-Ck35/16 and Pas-Ck36/16. Further analysis of samples using haemagglutination inhibition assay was done to make sure that isolates were NDV, using specific sera provided by VETMA, Surabaya. Based on biological characterization, MDT was about 100-120 hpi and
ICPI was about $0.12-0.37$ (Table 1). The results have shown that all isolates were lentogenic strain. RT-PCR method with primers that are specific to lentogenic strains has also shown positive results. RT-PCR products visualised in $1.5 \%$ agarose gel under UV transilluminator was shown on Fig. 1.

\section{Homology analysis}

Based on the results of homology analysis of isolates, Sby-Ck01/13, Blt-Ck03/13, Sby-Ck35/16, and Pas-Ck36/16 had high homology, but Blt-Ck02/13 did not have high homology. Complete data are shown in Table 2.

\section{Phylogenetic relationship of NDV from East Java}

The relationship between positive samples obtained in this study and other NDVs available in GenBank was illustrated using a phylogenetic tree of the partial HN gene sequence of the 5 sequences obtained in the study and other GenBank sequence of NDV (Fig. 2). From the tree, Pasuruan isolate (Pas-Ck36/16) was different compared to other isolates in East Java, Indonesia. The Pasuruan isolate belonged to class I NDVs - low-virulence strain. 


\section{Epitope prediction of $B$ cell}

The $\mathrm{B}$ cell epitope is a specific antigen region that has a high interaction with $B$ cell lymphocyte. As a result, B cell could produce the antigen-specific antibody and memory B cell. According to epitope predictions, samples that had high number of epitope were Sby-Ck01/13 (Table 3) and Pas-Ck36/16 (Table 4).

\section{DISCUSSION}

Vaccination is the most important way to prevent NDV infections (Wang et al., 2015). Many types of vaccines have been used, but NDV circulating in the field are different from the viruses used for vaccine causing outbreaks (Dimitrov et al., 2017). In addition, exotic NDV can also infect poultry in Indonesia. Therefore, it is very important to find the new variant and original isolate from native chicken to develop new vaccines.

In this study, we have analysed variations in the NDV genome in Indonesia, which have caused outbreaks in some poultry in the country. The poultry vaccine used in Indonesia comes from various countries and different strains, causing different viral properties. The $\mathrm{HN}$ protein of NDV has responsibility to induce antibody, as well as attachment between the outer membrane protein of virus and cell receptors (Absalon et al., 2019).

Five NDV isolates obtained from an outbreaks in East Java, Indonesia, were characterised to determine the pathotype of the virus. Pathogenicity tests showed that all isolates were lentogenic strains. All isolates demonstrated some pathogenicity in embryonated eggs and one-day old chicken. The results have shown that native chicken may not only be a natural reservoir of NDV, but also susceptible to exotic NDV originating from migratory birds that play an important role in the transmission and act as the main reservoir of the virus (Zhu et al., 2018).

It was recently discovered that there was a significant difference between viruses circulating in the field and viruses used for vaccines. Although ND vaccines have cross protection properties, in terms of biological characteristics, they are particularly different in inducing an immune response. This plays an important role in the epizootiology and the spread of the disease (Munir et al., 2012). In the last 5 years, the dominant type of NDV in Indonesia is genotype VII, while the vaccine used is Lasota which belongs to genotype II. So, there is a mismatch between viruses circulating in the field and viruses used for vaccines (Fernandes et al., 2014).

Table 2. Homology of gene encoding HN protein of NDV in Sby-Ck01/13, Blt-Ck02/13, BltCk03/13, Sby-Ck35/16 and Pas-Ck36/16 compared to LaSota vaccine as positive control

\begin{tabular}{llrrrrrr}
\hline No & Isolate & LaSota/16 & $\begin{array}{l}\text { Sby- } \\
\text { Ck01/13 }\end{array}$ & $\begin{array}{l}\text { Blt- } \\
\text { Ck02/13 }\end{array}$ & $\begin{array}{l}\text { Blt- } \\
\text { Ck03/13 }\end{array}$ & $\begin{array}{l}\text { Sby- } \\
\text { Ck35/16 }\end{array}$ & $\begin{array}{l}\text { Pas- } \\
\text { Ck36/16 }\end{array}$ \\
\hline 1 & LaSota/16 & $100 \%$ & & & & & \\
2 & Sby-Ck01/13 & $94 \%$ & $100 \%$ & & & & \\
3 & Blt-Ck02/13 & $94 \%$ & $100 \%$ & $100 \%$ & & & \\
4 & Blt-Ck03/13 & $94 \%$ & $100 \%$ & $100 \%$ & $100 \%$ & & \\
5 & Sby-Ck35/16 & $94 \%$ & $100 \%$ & $99 \%$ & $100 \%$ & $100 \%$ & \\
6 & Pas-Ck36/16 & $99 \%$ & $94 \%$ & $93 \%$ & $94 \%$ & $94 \%$ & $100 \%$ \\
\hline
\end{tabular}

BJVM, 24, No 2 


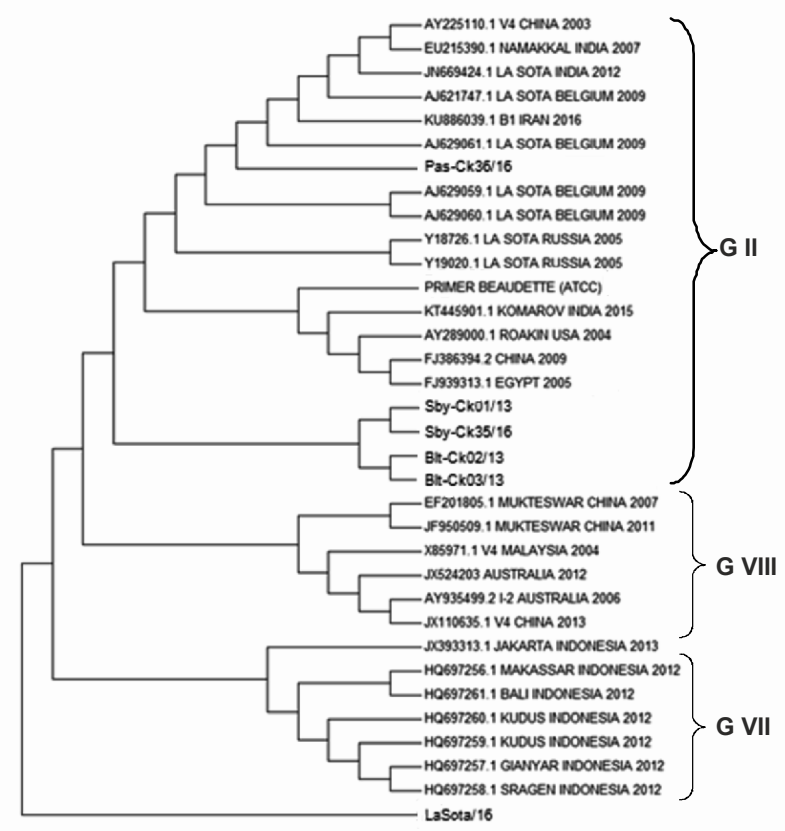

Fig. 2. Phylogenetic tree of partial HN gene nucleotide sequences of Newcastle disease virus (NDV). Beaudette strain as primer resource.

Table 3. Epitope prediction of Sby-Ck01/13

\begin{tabular}{ccclcr}
\hline No & Start & End & Peptide & Length & Log score \\
\hline 1 & 10 & 23 & ENDEREGKAPDIPD & 14 & 19.382 \\
2 & 45 & 62 & GGQHTRSCRYTDQNFQGR & 18 & 10.429 \\
3 & 74 & 84 & GCSGDIASGPV & 11 & 9.010 \\
4 & 93 & 97 & HNYER & 5 & 3.015 \\
5 & 108 & 127 & CEQQRVGGTYPPRLYRGDRQ & 20 & 16.944 \\
\hline \multicolumn{7}{l}{ Total } & \multicolumn{5}{c}{} \\
\hline
\end{tabular}

Based on phylogenetic analysis conducted, nucleotide sequences of HN genes might be different from isolate Pas$\mathrm{Ck} 36 / 16$ and the other isolates, as shown in Fig 2. In this study, one isolate from Pasuruan (Pas-Ck36/16) district was like the original ND viruses in nature because NDV still circulates in environment.

In our study, we predicted the B cell epitopes of the region of $\mathrm{HN}$ protein based on the BepiPred method on IEDB. These methods were used to predict specific areas in proteins that bind to the $\mathrm{B}$ cell receptor, and must be on the surface and immunogenic. Bepipred linear epitope prediction tool is the program based on a hidden Markov model. The best single method to predict linear epitope and a trend scale has the positive predictions that are characterised by E as B cell linear epi- 
Table 4. Epitope prediction of Pas-Ck36/16

\begin{tabular}{ccclcr}
\hline No & Start & End & Peptide & Length & Log score \\
\hline 1 & 10 & 21 & ENDEREGKALDV & 12 & 11.326 \\
2 & 47 & 59 & TRSCRHTDDFQGR & 13 & 8.701 \\
3 & 75 & 83 & DIQASGPVS & 9 & 6.885 \\
4 & 91 & 95 & HNYER & 5 & 3.015 \\
5 & 109 & 126 & QWVGGTYPPRLYRGDRQ & 18 & 14.152 \\
\hline \multicolumn{7}{l}{ Total } & & 5 & & \\
\hline
\end{tabular}

tope (Erik et al., 2006). B cell epitope is accessible and antigenic (Vita et al., 2015).

To prevent NDV in Indonesia, a variety of containerised strains in the form of live vaccines and inactive vaccines are used. Live vaccines are mostly formulated from lentogenic strains in the form of attenuated vaccines, but sometimes are also formulated from genotypes II such as B1, $\mathrm{C} 30$, and Beudatte. There is also a recombinant vaccine containing the $\mathrm{HN}$ and $\mathrm{F}$ coding genes of genotype $\mathrm{V}$. That is probably the cause of the changes in the new varian circulating in the field (Afonso $\&$ Miller, 2014). Therefore, even though vaccinations have been carried out, they still cannot stop ND outbreaks in Indonesia. Although the differences are likely to be geographically determined, the original viruses circulating in nature are more stable than attenuated vaccines. Further work should be performed is to determine whether the NDV isolate from Surabaya will be used in vaccine development to minimize infected chickens or not.

In conclusion, our experiment showed five lentogenic isolates of NDV: SbyCk01/13, Blt-Ck02/13, Blt-Ck03/13, Sby$\mathrm{Ck35/16}$ and Pas-Ck36/16. Based on homology and phylogenetic analysis, it was shown that one isolate from Pasuruan district (Pas-Ck36/16) was like the original ND viruses in nature.

\section{ACKNOWLEDGEMENTS}

We are grateful to the team in the research group of Newcastle disease virus. The hard work together gave rise to many kind ideas to develop knowledge and research in the future. This research supporting by Hibah Mandat University of Airlangga in 2018 through faculty and institution of research innovation, University of Airlangga, grant number 886/UN3/2018.

\section{REFERENCES}

Absalon, A. E., D. V. Cortes-Espinosa, E. Lucio, P. J. Miller \& C. L. Afonso, 2019. Epidemiology, control, and prevention of Newcastle disease in endemic regions: Latin America. Tropical Animal Health and Production, 51, 1033-1048.

Afonso, C. L \& P. J. Miller, 2014. Newcastle disease virus. In: Manual of Security Sensitive Microbes and Toxins. ed D. Liu, CRC Press, Boca Rato, pp. 689-698.

Anayet, H., H. Mehjabeen \& A. Jibran, 2013. A computational assay to design an epitope-based peptide vaccine against Saint Louis Encephalitis virus. Bioinformatics and Biology Insights, 7, 347-355.

Bello, M. B., Y. Khatijah, I. Aini, H. B. Mohd, P. H. P. Ben \& R. O. Abdul, 2018. Diagnostic and vaccination approaches for Newcastle disease virus in poultry: The current and emerging perspectives. Bio- 
Molecular characterisation of Newcastle disease virus exotic isolate in East Java, Indonesia

medical Research International, $\mathbf{2 0 1 8}$ $1-18$.

Dharmayanti, N. I, R. Hartawan, D. A. Hewajuli \& R. Indriani, 2014. Phylogenic analysis of genotype VII of New castle disease virus in Indonesia. African Journal of Microbiology Research, 8, 1368-1374.

Dimitrov, K. M., C. L. Afonso \& P. J. Miller, 2017. Newcastle disease Vaccines - a solved problem or a continuous challenge? Veterinary Microbiology, 206, 126-136.

Erik, J., P. Larsen, O. Lund \& M. Nielsen, 2006. Improved method for predicting linear B-cell epitopes. Immunome Research, 7, 1-7.

Fernandes, C. C., A. M. Varani, E. G. Lemos, V. F. de Miranda, K. R. Silva, F. S. Fernando, M. F. Montassier \& H. J. Montassier. 2014. Molecular and phylogenetic characterization based on the complete genome of a virulent pathotype of Newcastle disease virus isolated in the 1970s in Brazil. Infection, Genetics and Evolution, 26, 160-167.

Miller, P. J., C. L. Afonso, J. E. Attrache, K. M. Dorse, S. C. Courtney, Z. Guo \& D. R. Kapezynski. 2013. Effects of Newcastle disease virus vaccine antibodies on the shedding and transmission of challenge viruses. Developmental and Comparative Immunology, 41, 505-513.

Miller, P. J., R. Haddas, L. Simanov, A. Lublin, S. F. Rehmani, A. Wajid, T. Bibi, T. A. Khan, T. Yaqub, S. Setiyaningsih \& C. L. Afonso, 2015. Identification of new sub-genotypes of virulent Newcastle disease virus with potential panzootic features. Infection, Genetics and Evolution, 29, 216-229.

Munir, M., M. Cortey, M. Abbas, Z. A. Qureshi, F. Afzal, M. Z. Shabbir, M. T. Khan, S. Ahmed, S. Ahmad, C. Baule, K. Stahl, S. Zohari \& M. Berg. 2012. Biological characterization and phylogenetic analysis of a novel genetic group of Newcastle disease virus isolated from outbreaks in commercial poultry and from backyard poultry flocks in Pakistan. Infection, Genetics and Evolution, 12, 1010-1019.

Nakamura, K., M. Ito, T. Nakamura, Yu. Yamamoto, M. Yamada, M. Mase \& K. Imai. 2014. Pathogenesis of Newcastle disease in vaccinated chickens: Pathogenicity of isolated virus and vaccine effect on challenge of its virus. The Journal of Veterinary Medicine Science, 76, 31-36.

OIE (Office International des Epizooties). Newcastle Disease. In: Manual of Diagnostic Tests and Vaccines for Terrestrial Animals. Chapter 2.3.14., pp. 576-589, https://www.oie.int/doc/ged/ D12008.PDF (21 October 2019 date last accessed) .

Su, Qi., Y. Li, Y. Zhang, Z. Zhang, F. Meng, Z. Cui, S. Chang \& P. Zhao, 2018. Newcastle disease virus-attenuated vaccine LaSota played a key role in the pathogenicity of contaminated exogenous virus. Veterinary Research, 49, 1-11.

Tamura, K., G. Stecher, D. Peterson, A. Filipski \& S. Kumar. 2013. "MEGA6: Molecular evolutionary genetics analysis version 6.0". Molecular Biology and Evolution, 30, 2725-2729.

Vita, R., J. A. Overton, J. A. Greenbaum, J. Ponomarenko, J. D. Clark, J. R. Cantrell, D. K. Wheeler, J. L. Gabbard, D. Hix, A. Sette \& B. Peters, 2015. The Immune epitope database (IEDB) 3.0. Nucleic Acids Research, 43, 405-412.

Wang, J. Y., W. H. Liu, J. J. Ren, P. Tang, N. $\mathrm{Wu}, \mathrm{H}$. Y. Wu, C. D. Ching \& H. J. Liu. 2015. Characterization of emerging Newcastle disease virus isolates in China. $\mathrm{Vi}$ rology Journal, 12, 1-21.

Xiao, S., A. Paldurai, B. Nayak, A. Samuel, E. E. Bharoto, T. Y. Prajitno, P. L. Collins \& S. K. Samal, 2012. Complete genome sequences of Newcastle disease virus strains circulating in chicken populations of Indonesia. Journal of Virology, 86, 59695970.

Xiao, S., B. Nayak, A. Samuel, A. Paldurai, M. Kanabagattebasavarajappa, T. Y. Prajitno, E. E., Bharoto, P. L. Collins \& S. K. Samal, 2012. Generation by reverse gene- 
tics of an effective, stable, live-attenuated Newcastle disease virus vaccine based on a currently circulating, highly virulent Indonesian strain. Plos One, 7, 1-15.

Zhu, H., H. Zhang, Y. Wang, D. Ciren, H. Dong, Q. Wu, M. Ur Rehman, F. Nabi, K. Mehmood \& J. Li, 2018. Phylogenetic and pathotypic characterization of Newcastle disease virus in Tibetan chickens, China. Pesquisa Veterinária Brasileira, 38, 37-40.
Paper received 29.08.2019; accepted for publication 06.10.2019

\section{Correspondence:}

Fedik Abdul Rantam,

Jl. Mulyorejo, Kampus C Unair, Surabaya, 60115, Indonesia, email : fedik-a-r@fkh.unair.ac.id 